\title{
A Controversial Political View: Rorty’s Moral Finitism and Religion in the Public Square
}

\author{
Joaquín Jareño \\ University of Murcia
}

\begin{abstract}
Richard Rorty's moral finitism is based on some ideas from John Stuart Mill's work On Liberty. For Rorty, religious truths would be the main obstacles for the development of freedom and, at the same time, for human happiness. Rorty introduces the concepts of contingency and literary culture to express the situation of personal moral development, stressing that our life must be seen as an endless narration. So, there is no fixed development given once and for all. Rorty's anticlericalism is also based on the idea that the creation of clerical institutions and hierarchies is dangerous in the sense that they pose demands which go beyond individual perspectives and make religious obligations be prior to moral ones. Nevertheless, there are some misconceptions in Rorty's position when he discusses the idea of moral obligation and the relationship between religion and religious institutions.
\end{abstract}

Keywords: religion, public square, moral finitism, contingency, narrative, anticlericalism, religious institutions

Richard Rorty once wrote that anything we needed in Ethics had been expressed clearly by John Stuart Mill in his work On Liberty. ${ }^{1}$ Though not untouched by criticism, ${ }^{2}$ Mill's ideas have been highly influential in shaping the liberal conception of individuals. Mill would hold that moral autonomy - the ability to develop our own code of conduct independent of higher authority - is central to the task of forming our identity and personality. This process of individualization is, according to Mill, what lends our dignity as rational beings and gives us the means by which to fulfill our aspirations; liberty holds center stage in his conception of ideal human existence. The only limit to this mode of development is the so-called "harm principle," according to which we must not act in such a way that we prevent others from pursuing their own goals and interests.

Speaking of moral foundations, understood as a set of fixed premises from which moral action is justified, is thus difficult in Mill's philosophy, given its focus on the importance of autonomy for human fulfillment. This primacy of the individual calls into question the idea of moral foundations as well as the possibility of appealing to any supra-individual authority ${ }^{3}$ understood as a guarentee and source of the ethical demands affecting each one of us in questions of politics or morality. Rorty applies Mill'sideas to his discussion of the role of religion in the public sphere while diminishing the scope and influence of its basic principles in the private realm as well.

Religion appeals to absolute and permanent truths, submitting personal will to that of a divine being. Such an appeal allows to absolute and non-disputable definiton of what constitutes a worthy life. For Rorty, then, religious truth would be the main obstacle to the development of freedom and, at the same time, of human

Joaquín Jareño, Ph.D., Department of Philosophy, University of Murcia, Spain; main research field: Wittgenstein, Political Philosophy, Moral Philosophy, Relativism (moral and epistemological), and Philosophy of Culture. Email: humanities2011@gmail.com. 
happiness. In what follows, I will examine and critique Rorty's criticism of moral commitments coming from religious beliefs as well as his negative view of the Church's influence on public activities. My basic concern will be that of the Catholic view on religion and public affairs.

Let us first explore some basic ideas of Rorty's relevant to the discussion at hand. Rorty would hold that identifying a supra-individual will as the source of morality leads us to define submission to such will as moral improvement: Our behaviour is measured and evaluated by means of its nearness to the authority. This, in Rorty's perspective, annihilates the individual as a moral subject. He/she has to resign his/her personal initiative in order to fit with those demands coming from that supra-individual will. Besides, if something is objectively true (objectively good), then no one can refrain from doing it.

As an alternative to objective truth, Rorty proposes a human finitism stressing the contingency ${ }^{4}$ of moral concepts $^{5}$ with respect to human happiness. ${ }^{6}$ Achieving this happiness is of paramount importance and our morality is shaped by our personal considerations of what is most useful in attaining that end, restricted only by the aforementioned "harm principle." Hence, practically speaking, morality is context-bound rather than absolute. Furthermore, since we are empirical beings, we cannot be submitted to unconditional moral demands, exigencies that, by definition, would be absolute and out of reach. According to Rorty, the only way to surmount this distance is by renouncing objective morality as vacuous and lacking practical interest. Pragmatist that he is, Rorty holds that there is nothing beyond our own finite being and the relationships we establish with one another. We do not need any philosophical or religious foundation to back or guarantee our happiness.

To clarify the scope of such criticism, it is useful to reflect on how Rorty understands the concepts of truth and self and stresses the importance of their contingency. Out of principle, Rorty rejects a universalistic conception of truth ${ }^{7}$ and, together with it, any kind of foundationalist value we may want to attach to it. The search for truth is nothing else than our aspiration to justify a set of concrete beliefs before any possible audience. In reality, we can only guarantee that, at least for the time being, we have successfully justified a particular belief. This is what makes truth into something contingent: we could find ourselves unable to justify the same belief or set of beliefs before an unexpected audience. For Rorty, foundationalism is misguided in assuming that beliefs are attempts to picture something called reality by matching it.

The same idea is associated with moral discourse: There are not (and cannot be) moral truths (what is "truly good”) as such. The contingency of moral judgments, then, is connected with the impossibility of achieving a unified discourse concerning any particular manifestation of our moral sense. Truth, by this understanding, is the outcome of an agreement on practical consequences coming from a specific belief. Thus, according to Rorty, truth is but a sociological generalization, and general moral demands are merely social practices resulting from public agreement; we cannot appeal to any authority higher than ourselves in discussing such matters. The aspiration to ultimate truth is the same as the desire of achieving a unique and unified lexicon of demands in the domain of human behaviour, which would also serve as a guide for personal realization. From Rorty's perspective, however, this means a limitation of the progressive and perfective character of the human will. Moral demands would show the minimum commitments the individual must acquire, apart from the personal projection of his/her desires or aspirations, in order for a given society to work. It means that moral demands must be measured by the consequences they have for moral actors, which unavoidably makes them be contingent: In the end, such demands are social practices and nothing more.

All this prevents any discussion of moral matters from appealing to truth, what is morally true, understood in an absolute or objective sense as a criterion to evaluate our proposals. We therefore cannot ask for moral 
statements to have universal value. To assert that they do is but to show the aspiration that they are expanded so as to become valid for any individual. But this is a difference in the practical order, not in the metaphysical one. It is just that we do not expect any counterargument to appear in order to contradict our point of view. We seem not to need a substantive notion of truth.

Another idea relevant to the topic we are dealing with is the idea of the self. Rorty holds a special interest in the historical conception of selfhood on the development of personal identity. Self is, from his perspective, an empty word. It belongs to those metaphysical concepts whose value actually cannot be separated from concrete and spatio-temporal circumstances, which is to say that they have no value apart from such circumstances. Rorty's criticism to self understood in metaphysical terms is a criticism of a closed structure, understood as an abstract concept where all the particular instances of individuality coincide. Nevertheless, what characterizes the individual is just the opposite. Life must be seen as an endless narration, reviewable if the circumstances and interests of the individual so demand. There is no unique formula that expresses human nature, so that there can be no unique discourse that make moral demands subordinated to something beyond concrete historical human beings and personal stories. This is what makes our convictions contingently justified. There is no final language for the description everyone of us makes of him/herself, so that the redescription is endlessly possible and is not submitted to unalterable criteria; morality is reduced to the expression of our concrete feelings towards our fellow neighbours. The basic truth, then, is that it is the chosen lexicon that creates — and recreates - the self. However, there still remains the question about how to solve moral doubts within a process characterized by a contingency assumed as a substantive element.

To what extent applies all this to religious discourse? Moral tradition talks of purification as the process of progressive improvement in relation to a criterion of moral exigency-a system of moral truths above the individual. Moral truth is understood as the identification between our individual moral commitments and the superior criterion of moral demand. In this sense, purification is defined as progression towards such identification, which points at the existence of a redemptive truth that raises us beyond the limitations of our human condition.

This idea of truth has no place in Rorty's philosophy. Rortyan pragmatism characterizes itself as liberation from the dogmatism of religion, which necessarily entails a moral orthodoxy governing the lives of the faithful. Rortyan anticlericalism has to do with the existence of a fundamental orthodoxy as well as with the organisations that maintain it. For Rorty, beliefs must be classified by their utility so that their dogmatics aspirations are, at best, the end product of social practices. We cannot see beliefs from a metaphysical point of view. This anti-dogmatism echoes the Enlightenment tradition of attempting to secularize every aspect of society. Yet this tradition also created dogmas of its own-which, similar to religious dogma, everyone is expected to follow. Let us briefly comment on this topic in order to understand the overall position of Rorty.

According to most traditional Western philosophy, the human ability to apprehend the requirements for moral purification from reason and answer to those demands is what makes us rational instead of irrational. Philosophical truths remain over/beyond human beings; yet when apprehended, there is a certain extent to which the individual can be redeemed, or at least rescued from the wrong way of living. Without such universal criteria to evaluate the rightness of individual conduct, we remain without guiding principles to justify our decisions, our moral evaluation. But, for Rorty, the meaning of our action is not guided by principles of this kind. The evolution of human life is a process open to ongoing recreation, which excludes any end decided beforehand or fixed once and for all. However, the assertion that such radical openness, such unrestricted 
freedom will unavoidably lead us to solidarity and peaceful coexistence is a prejudged conception. We have no way to guarantee it.

Taking into account the openness of the individual for his/her recreation, Rorty proposes a literary culture where the novel constantly opens new possibilities for us to change our lives and to enlarge ourselves. Acquiring maximum coherence in our understanding of absolute truth is no longer the goal: Rather, we would seek to be in relationship with others who show us different lifestyles. The novel allows us to understand variety in human life, in order that we might realise the contingency in our own moral vocabulary. Thus, the only purification is what comes from our recognition of our own contingency. This sort of openness to others leads us out of our ego-centrism and, at the same time, of our egoistic tendencies. Purification consists, then, in this permanent enlarging ourselves by means of the contact with others, with their lives—-their stories—which makes us more and more sensitive to the emotions others transmit.

We have to take into account, however, the difficulties arising from the need we have to give these texts an interpretation and, in turn, from the effective interpretation we give them. Such interpretation appears as the foundation for solidarity as far as it allows encounters where we realise the many possible ways to give meaning to our life. The problem arises when we make use of an intentionalist terminology. That is, the coincidence between the intentions by means of which author and reader interpret word sequences is essential to actual moral impact, what would make possible a moral improvement on the reader. Nevertheless, Rorty "explicitly states that the pragmatist oriented interpreter does not care about the author's intentions" (Poulakka $2008,31)^{8}$ the rigid limitations of which could be overcome by imagination. Giving precedence to the author's understanding of the text would have had the value of a moral imperative; Rorty's response, by contrast, would leave texts open to indeterminacy; the results would be closely akin to the consequences of Quinean extensionalism.

Though Rorty's proposal may seem quite sound on the surface, it also raises questions that must be discussed. First, Rortyan literature contains echoes of a postmodern revision of Auguste Comte's famous distinction between stages in the development of cultures and civilizations. There is also in Rorty's assessment a sort of graduality where every stage reinterprets the previous one: Religious truth is surpassed by philosophical truth, which in turn is replaced by literary truth - that is, by the dissolution of a unitary discourse in the multiplicity of narratives. ${ }^{9}$ If this multiplicity is taken as truth-in the sense used by John Stuart Mill-then every moral commitment must be understood as one possibility among others. That becomes our guide to reinterpreting the meaning of those texts which historically have given shape to the religious way of life-the Bible, for instance, or the works of Homer. And this is what makes multiplicity into a normative pattern, ${ }^{10}$ due to the fact that it is the means by which the individual can assimilate religious proposals as possibilities of personal redescription or ways of enlarging oneself. As a result, the multiplicity of truth becomes an essential truth of the Pragmatist program, something needed to give coherence to the whole discourse.

This is also how Rorty's anti-clericalism, as well as his rejection of any organization or hierarchy by means of which a group of beliefs becomes a creed, must be understood. As far as those religious beliefs are not evaluated according to the role—and consequences — they play in our own lives, we risk finding ourselves with a dogmatism which invades public life, undermining our liberty to pursue personal interests. So, according to Rorty, the creation of clerical institutions and hierarchies is politically dangerous in the sense that they pose demands which go beyond individual perspectives and aspirations, applying such demands to the public 
domain when submitting individual wills to a general one; this obliges us all to make distinctions between moral and immoral with reference to something beyond the level of the individual. This is what leads Rorty to say: "It is mostly religion above the parish level that does the damage" (Rorty 2003, 141). ${ }^{11}$ We must therefore, according to his way of thinking, come to the conclusion that religious institutions are dangerous for the health of a democratic society. ${ }^{12}$ Rorty, in keeping with this, argues for a privatizing of religion, in which religious commitments would be devoid of political consequences, that is, in which churches would have no right to impose on believers any special view with respect to political matters. Privatizing religion would deprive it of the demanding strength of a truth formed in the continuance of the exigencies imposed by the churches, exigencies that would stop human impulses and would allegedly limit the reach of social and moral renewal. Churches force their members into servitude insofar as institutions exert moral and ideological power on them. For Rorty, we do not need churches if all we want is social cooperation: We just need science and common sense. ${ }^{13}$ In the end, everyone has right to feel whatever he/she wants in the private realm but can come out with public proposals only if they clearly help to have social benefits and achievements. The basic danger of established religion derives from connecting religious faith to truth, and with having institutions as guardians and custodians of such truths. ${ }^{14}$ Getting rid of these truths-and institutions-would allow us to change power for charity; or so thinks Rorty.

Nevertheless, it is quite difficult to imagine a religion apart from a tradition, devoid of an orthodoxy. Christian dogma results from the fixation and demarcation of the Church's truths since its inception as an institution. What we today know as Christianity we know it thanks to the legacy and work of a whole tradition, which has separated orthodox doctrines from unorthodox ones, the canonical texts from the apocryphal ones (let us remember Pope Saint Damasus, for instance). It is this Tradition that has made it possible for us-and for Rorty—to talk about religion as we do. Otherwise, we could only speak of religious feeling from a purely emotional perspective. So, if the Church as institution is the target of Rortyan secularism, ${ }^{15}$ there remains little of what Rorty would wish to fight, and there is no need for a discussion.

For Rorty, the criterion to talk about the value and influence of any ecclesiastical institution is its moral repercussions for everyday believers, measured in terms of the human misery or benefit coming from churches (defined, of course, according to Pragmatist criteria). For Rorty, we need religion as compensation for all the suffering and pain —mainly resulting from social injustices—which afflicts mankind. This, in turn, would give credence to the suspicion that ecclesiastical institutions would be interested in the maintenance of such unfairness (or cruelty, and the use of $i^{16}{ }^{16}$ ), quoting biblical passages in support of their views. For this reason, we should ignore religion at public debate, while at the same time taking morals as the human business par excellence. According to the new schema Rorty wants to promote, this morality would be interpretive rather than imperative, something submitted to discussion, dialogue, and debate. This is, for Rorty, what makes the pursuit of morality superior to the quest for religious truth, ${ }^{17}$ because it is not only closely connected with the autonomy of individuals but also gives the answers to their real needs and interests. There is, according to this model, a primacy of moral duties over religious ones.

We must consequently become aware of the aspiration to solidarity as a crucial facet of moral concerns. This, from Rorty's point of view, is the basic exigency which the construction of our personal identity must fulfil. Yet this is a fundamental point in Christian doctrine as well. Strictly speaking, this aspiration would appear as a contingent demand - that is, the multiplicity of narrations may make appear a lexicon where such demand is not compulsory, and this would have to be accepted as a possibility as well. For Rorty, there are 
some non-contingent demands, this being one of them. Rorty greets the religious appeal to take care of fellow men but separates it from its religious connections; once again, morality is given primacy over religion. ${ }^{18}$ No special justification can come from religious commitments; our duties to our fellow citizens must be fulfilled as a matter of civic responsibility. This would not eliminate the religious conscience; rather, the religatio would be given in relation with the rest of human beings. Unfastening from God, the possibility of believing in human capacities and potentialities, would be the unique choice. ${ }^{19}$ This would be the real conversion, as opposed to traditional religious conversion. Public institutions would take on social activities formerly led by churches, leading the way to a civic religion built on the foundation of social cooperation. ${ }^{20}$

Yet this demand, too, is at the heart of Christian morality, in which our duty to our fellow men is the basis of morals. Our duty to God is intrinsically linked with our duty to the rest of humanity so that religious political action may perfectly entail global solidarity and does not need to understand justice as larger loyalty. It cannot be otherwise: ${ }^{21}$ the radicality of the commandment "love your enemy" clearly states how our love to God must be expressed and the obligations we have toward him. Such radicality appears in the formula: "Anyone who says, 'I love God' and hates his brother is a liar, since a man who does not love the brother that he can see cannot love God, whom he has never seen” (1 John 4:20). ${ }^{22}$ It does not make any sense loving God apart from loving human beings. There are many biblical texts in support of this idea, from The Good Samaritan parable (Luke 10:29-37) to the narration of the central commandment, which is considered to be Christ's testament (John, 13:34-35). In loving our fellow neighbours, the Law (Pentateuch) and the prophets are condensed. The theological and historical importance of this is seen in that for Jewish tradition the Law is the highest expression of God's will, so that its fulfilment is the essence of religion itself; and the prophets are the ones who guide the people of Israel by remarking the tempo of God's covenant with his people, which actually gives the meaning for the history and development of Israel as the chosen people.

All this shows that the imperative character of the commandment of love is an essential part of the Christian faith. The Church, as an institution, cannot omit evangelical precepts; they act as a guide for shaping its doctrinal core. The apostolic Church — the Church in its earliest years—understood this to be the case soon after Christ's death: the unavoidable connection between action and the preached beliefs and the vacuity of faith without works (James 2:14-26). Salvation is thereby associated, not with the arbitrary will of God, but-together with God's generosity - with the human capacity to choose. Obligation is only comprehensible from freedom. All this explains why our basic solidarity is with our fellow human beings. But God's authority is what makes morals imperative, given that no special narrative-in Rorty's moral terms - can go beyond suggestions, or plain orientations about good, bad, and so forth. ${ }^{23}$ The current transformation of the concept of moral guilt would reduce the obligation of re-establishing the order broken through transgression, since the result of the re-description process could be understood as that guilt has not broken an order that has to be necessarily kept. The resultant disappearance of the idea of sin is one of the major problems of our society. This idea is re-formulated by sociological figures such as deviant behaviour and normal behaviour. In this manner, moral error is dissociated from its ontological involvements, so that it is exempt from this connection to transcendent order.

Contrary to what Rorty says, all of this marks a change in the relationship between God and humanity, at least in terms of our moral commitments (and the practical consequences attached to them). This change appears very clearly in the formula, "since what I want is love, not sacrifice" (Hos. 6: 6/Mt. 9: 13). At the same time, the list of merciful works (Mt. ch. 25: vv. 30-46) — which are the reasons to justify and explain our place 
in the final judgment ${ }^{24}$ - clearly states that our basic solidarity is towards our fellow human beings. No Christian Church can pose anything different from the central commandment of love. The link it has with it is, so to say, imperative, and the Church must render account to a divine authority for how well its leaders have carried out its mission. This idea also has a permanent expression in the Ten Commandments, which work as a compendium of the basic moral demands any human being must assume towards his/her neighbours. Such commandments are taught as inalienable precepts, founding moral action, and the link with our obligations towards others is clearly shown from the forth commandment on. The Catechism of the Catholic Church, for instance, divides the Ten Commandments into two parts. The second one, significantly, is titled, "You Shall Love Your Neighbour as Yourself.”

Nothing of this sort applies to the anticlerical individual and his/her interpretation of morality. He/she does not feel the same demand. The strength of his/her obligation is in close connection with the sympathy he/she may feel towards others: The reading of a text can compel to a species of commitment due to some sort of sympathy, but it cannot exert obligation of any kind unless he/she has given special authority to it. Nevertheless, there is a special task for a believer when taking part in his/her duties as citizen. Among other kinds of influence it has, religion plays a specific role in his/her everyday life by way of the obligations it imposes on believers, and in this way acquires a public relevance. A believer cannot impose his/her hierarchies of values based on faith. ${ }^{25} \mathrm{He} / \mathrm{she}$ can only claim what belongs to our shared humanity. ${ }^{26}$ But the fulfilment of his/her duties is basically rooted in his/her convictions and the demands to treat his/her fellow neighbours as he/she treats him/herself. A good example of the implications those commitments carry on with them appears in the Pastoral Constitution Gaudium et Spes (Vatican II), ${ }^{27}$ where the duties believers have towards the rest of human beings are clearly stated. And those implications come not only because of their being human, but mainly because of their believing condition:

All Christians must be aware of their own specific vocation within the political community. It is for them to give an example by their sense of responsibility and their service of the common good. In this way they are to demonstrate concretely how authority can be compatible with freedom, personal initiative with the solidarity of the whole social organism, and the advantages of unity with fruitful diversity. They must recognize the legitimacy of different opinions with regard to temporal solutions, and respect citizens, who, even as a group, defend their points of view by honest methods. Political parties, on their part, must promote those things which in their judgement are required for the common good; it is never allowable to give their interests priority over the common good. ${ }^{28}(1965,75)$

Apart of those clearly practical reasons, the chances for religions to be discussed publicly must remain open. The possibility of discussion must not be precluded at any rate, that is, notwithstanding that religion can be understood by some as a conversation-stopper (as Rorty does), the consequences come as follows: "as John Stuart Mill said in 'On Liberty,' 'all silencing of discussion is an assumption of infallibility”' (Trigg 2008, 144), ${ }^{29}$ so that for the sake of the very discussion, religion must remain at the public sphere.

Rorty calls himself atheist. ${ }^{30}$ But an atheist, too, holds specific beliefs that make him/her to be what he/she is. Detaching beliefs from public activities—being political or whatsoever—seems to be a very difficult task to do, so atheist convictions and ideas must be evaluated by their practical consequences as well. If religion, as Rorty says, should remain secluded in the parochial domain — and become a private or semi-private issue, we are entitled to ask if the same should go for the atheist. He/she should have his/her specific commitments, in turn, estimated as if they should be secluded in the private sphere, that is, we should have to consider if we must privatize anti-clericalism as well. This would fit Mill's proposals in what concerns the autonomy of 
individuals from an ethical perspective-as well as what concerns the principle of non-interference in others' aspirations, due to the fact that, according to Mill, we must avoid the conflict between different proposals concerning what a worthy life may be.

In conclusion, if beliefs must be evaluated in terms of practical consequences, we cannot leave religious commitments out of the public square. What we have to do is evaluate if the specific commitments coming from those basic beliefs are working as they must. The examples of the influence of religion in social achievements are many. Nicholas Wolterstorff refers some that could be easily recognizable by Rorty: "Has the prominent role of religion in the American civil rights movements already been forgotten? Has its prominent role in the revolutions in South Africa, Poland, Romania, and East Germany already passed into amnesia?” $(2003)^{31}$ But, on the other side, we see that the ideal society vindicated by Rorty, where the practice of love and solidarity are the basic sources for action, ${ }^{32}$ is not justifiable from the anticlerical perspective. ${ }^{33}$

\section{Notes}

1. "Pragmatism as Romantic Polytheism," <http://www.nytimes.com/books/first/d/dickstein-pragmatism.html>.

2. Let us remember that Mill maintains a very personal perception of what a good life must include: search for knowledge, aesthetic pleasures, poetry, etc. (cf. Oskar Kurer, “John Stuart Mill: Liberal or Utilitarian?” European Journal of the History of Economic Thought, 6.2 (1999): 200-15). In this sense, see Mill's “Utilitarianism” (John Stuart Mill: On Liberty and Other Essays. Oxford: Oxford University Press, 1998. 140). Mill has been accused of social Darwinism and of having some sort of aristocratic intention in his social and political proposals. This is actually something that can be grasped from some of his writings. John Stuart Mill: “On Liberty” (John Stuart Mill, 74; “Representative Government,” John Stuart Mill, 224, 228, 229, 243, 260...).

3. A classical discussion on this topic appears in James Rachels' article: “God and Human Attitudes” (Paul Helm, Divine Commands and Morality. Oxford: Oxford University Press, 1981. 34-48). Rachels questions the possibility of being an autonomous moral agent and being submitted to God's will at the same time. For Rachels, if we accept any supra-individual moral authority, we must abandon our role as moral agents. He uses his argument to conclude that there cannot be any being with the title: "God".

4. Hoffnung Statt Erkentniss: Eine Einfuhrung in die Pragmatische Philosophie (Hope instead of Knowledge: An Introduction to Pragmatist Philosophy. Published in English as chapters 2-4 of Philosophy and Social Hope). Vienna: Passagen Verlag, 1994, chapter III; Contingency, Irony, and Solidarity, New York: Cambridge University Press, 1989, specially chapters 1 , 2, 3, 4 and 5; Philosophy as Cultural Politics. Philosophical Papers, Volume IV, Cambridge: Cambridge University Press, 2007, specially chapters 2 and 3 .

5. In some important respects, this idea can be traced back to John Dewey's work The Reconstruction in Philosophy (The Beacon Press), specially its chapter VII, on the reconstruction of moral concepts.

6. The need of looking for foundations alien to individuals' particular perspectives to justify morality has been called "Cartesian Anxiety." Michael Bacon, quoting Richard Bernstein (Beyond Objectivism and Relativism: Science, Hermeneutics, and Praxis. Philadelphia: University of Pennsylvania Press, 1983) gives a definition of such expression: "The fear that without a grounding outside of any particular human perspective, we are left adrift in a morass of relativism and nihilism” (“A Defence of Liberal Ironism,” Res Publica, 11.4 (2005): 405).

7. Objectivity, Relativism, and Truth. Philosophical Papers, Volume I, Cambridge: Cambridge University Press, 1991; Truth and Progress. Philosophical Papers, Volume III, Cambridge: Cambridge University Press, 1998; Hoffnung Statt Erkentniss (Hope instead of Knowledge), chapters I and II; Robert Brandom (ed.): Rorty and His Critics, Oxford: Blackwell Publishing Ltd., 2000, specially chapters $1,2,3$, and 11 .

8. Kalle Poulakka, “Literature, Ethics, and Richard Rorty’s Pragmatist Theory of Interpretation,” Philosophia 36.1 (2008): $29-41$, at 31.

9. Cf., for instance, Richard Rorty, “Comments on Pippin on James,” Inquiry 45.3 (2002): 351-8.

10. Something demanded from the contingency we want to ascribe to moral and religious discourse.

11. Richard Rorty, “Religion in the Public Square. A Reconsideration,” Journal of Religious Ethics 31.1 (2003): 141-9.

12. Rorty’s comments: Richard Rorty, Gianni Vattimo, Il Futuro Della Religione (The Future of Religion) (Milan: Garzanti Libri, s. p. a. 2005, edited by Santiago Zabala).

13. Roger Trigg stresses the weakness of such an idea when he writes: "Only a metaphysical belief that what exists must be restricted to what is accessible to science can justify paying attention to science, and banishing religion from our public places. This begs the question against religion in a spectacular way. It is denigrated because it is based on metaphysics, and not empirical science. Yet the denigration itself depends on metaphysical assumptions” (Religion in Public Life, Oxford: Oxford University 
Press, 2008, 197). Though Rorty is indeed strongly critical of the idea of truth in science, he supports the presence of science in the public sphere because it is a discourse open to discussion and able to promote agreement, on which the very idea of truth is dependent. At the same time, stating that all we need is science and common sense means that religion may be seen as illegitimate in the private realm as well.

14. Which, for Rorty, means political power.

15. Cf. Richard Rorty, "Religion in the Public Square...," 141.

16. In a highly controversial comment-and while surprisingly comparing Marxism with the Roman Catholic Church, Rorty writes: "At the end of the 20th century, Marxism is in the position of Roman Catholicism at the end of the 17th. By then the full horror of the Renaissance papacies and of the Inquisition had been made known. Many Christians thought that it would be best for the bishops of Rome to close up shop. Christianity, they pointed out, had long antedated the papacy, and would be much better off for its demise" (Richard Rorty, Achieving our Country, Cambridge, Mass.: Harvard University Press, 2001, 41). What these comments may show is lack of deep historical knowledge, and too much attention paid to the so called "Black Legend." Contemporary historians (Jean Dumont, Domínguez Ortiz, Stephen Haliczer, David Gitlitz, Norman Roth, John Edwards, Miguel Ángel García Olmo, etc.) have helped us to see the whole issue more accurately. As a matter of interest, one of the most renowned historians interested in the Spanish Inquisition, Henry Kamen, has clearly changed his mind since the first edition of his work: Inquisition and Society in Spain (reelaborated in 1985 and 1998), softening the content of his accusations against the Inquisition.

17. Nevertheless, this is quite a "modern" idea, that is, a typical proposal from Modernity which in turn would be justifying the ironist description, proper of the so called "postmodern point of view." Some Rortyan conclusions are typically "modern," in the sense that they express "modern" aspirations, as they were understood when the Enlightenment enthroned Reason. Anthony Giddens has interestingly and arguably stated that what we call "Post-modernity" is just a radicalization of "modern" ideas. It is that "Postmodernity” would be the final stage of "Modernity.” The Consequences of Modernity (Polity Press/Basil Blackwell).

18. In 2006, a then senator Barack Obama, while addressing a speech on religion and politics, said: "But what I am suggesting is this-secularists are wrong when they ask believers to leave their religion at the door before entering into the public square. Frederick Douglas, Abraham Lincoln, Williams Jennings Bryant, Dorothy Day, Martin Luther King —indeed, the majority of great reformers in American history — were not only motivated by faith, but repeatedly used religious language to argue for their cause."

19. This is what has led some authors to say that Rorty tries to reconcile "a yearning for the transcendent and sublime with a desire for human solidarity.” Jason Boffetti, “How Richard Rorty Found Religion,” First Things: A Monthly Journal of Religion and Public Life 143 (2004): 24-30. As a matter of fact, a recovery of religious feeling though "redescribed" seems to derive from some of his writings (cf. J. Boffetti, 28: "While insisting that he is profoundly anticlerical and antiecclesiastical, Rorty envisions a future America with quasi-churches serving a national religion of romantic polytheism”).

20. From a religious perspective, we depart from a specific conception of human condition, according to which we have a weakened nature in need of redemption.

21. What actually implies a strong attack on Rorty's ethnocentrism.

22. The Jerusalem Bible. Edited by Alexander Jones (1966), Philippine Bible Society.

23. Cf. Joseph Cardinal Ratzinger, Creación y Pecado (Creation and Sin) (Pamplona: Eunsa, 1992, 88).

24. What for a believer is the basic reference to understand punishment and reward. This idea of final judgment has been seen sometimes as the tool for the hierarchies to exert power on believers' consciences. Nevertheless, those hierarchies will have to be judged by their merciful works as well. And so the idea of a final judgment comes for them as well.

25. Benedict XVI, "Letter to Marcello Pera," Benedict XVI, Marcello Pera, Senza Radici. Europa, Relativismo, Cristianesimo, Islam (Without Roots. Europe, Relativism, Christianity, Islam) (Milan: Arnoldo Mondadori Editore, 2004).

26. The best known biblical text in support of it is the following: "Next they sent to him some Pharisees and some Herodians to catch him out in what he said. These came and said to him, 'Master, we know you are a honest man, that you are not afraid of anyone, because a man's rank means nothing to you, and that you teach the way of God in all honesty. Is it permissible to pay taxes to Caesar or not? Should we pay, yes or no?' Seeing through their hypocrisy he said to them, 'Why do you set this trap for me? Hand me a denarius and let me see it.' They handed him one and he said, 'whose head is this? Whose name?' 'Caesar's' they told him. Jesus said to them, 'Give to Caesar what belongs to Caesar—and to God what belongs to God.' This reply took them completely by surprise;” Mk. 12:13-17.

27. Promulgated by Pope Paul VI on December 7, 1965.

28. Gaudium et Spes (Joy and Hope), n. 75.

29. Roger Trigg, 144.

30. In this sense, atheism must be understood as anti-clericalism, a political—not metaphysical—point of view.

31. “An Engagement with Rorty,” Journal of Religious Ethics 31.1 (2003): 129-39.

32. How, then, could we make real Rorty's ideal based on 1 Corinthians, chapter 13? See Rorty's comments in Il Futuro della Religione (The Future of Religion).

33. His/her achievement would be contingent and never guaranteed nor clearly understood. There could be as many ideal societies as individuals are or can be, or depending on the multiplicity of narrations.

\section{Works Cited}

Bacon, Michael. “A Defence of Liberal Ironism.” Res Publica (The Public Thing) 11.4 (2005): 403-23. 
Bernstein, Richard. Beyond Objectivism and Relativism: Science, Hermeneutics, and Praxis. Philadelphia: University of Pennsylvania Press, 1983.

Boffetti, Jason. “How Richard Rorty Found Religion.” First Things: A Monthly Journal of Religion and Public Life 143 (2004): 24-30.

Brandom, Robert. Rorty and His Critics. Oxford: Blackwell Publishing Ltd., 2000.

Dewey, John. The Reconstruction in Philosophy. Boston Mss: The Beacon Press, 1948.

Giddens, Anthony. The Consequences of Modernity. Stanford: Polity Press/Basil Blackwell, 1990.

Kamen, Henry. Inquisition and Society in Spain. Bloomington: Indiana University Press, 1985.

Kurer, Oskar. “John Stuart Mill: Liberal or Utilitarian?” European Journal of the History of Economic Thought 6.2 (1999): 200-15.

Mill, John. On Liberty and Other Essays. Oxford: Oxford University Press, 1998.

Pope, Benedict XVI and Pera Marcello. Senza Radici. Europa, Relativismo, Cristianesimo, Islam (Without Roots. Europe, Relativism, Christianity, Islam). Milan: Arnoldo Mondadori Editore, 2004.

Pope, Paul VI. Pastoral Constitution Gaudium et Spes. <http://www.vatican.va/archive/hist_councils/ii_vatican_council/ documents/vat-ii_const_19651207_gaudium-et-spes_en.html>.

Poulakka, Kalle. “Literature, Ethics, and Richard Rorty’s Pragmatist Theory of Interpretation.” Philosophia 36.1 (2008): 29-41.

Rachels, James. “God and Human Attitudes.” Ed. Paul Helm. Divine Commands and Morality. Oxford: Oxford University Press, 1981. 34-48.

Ratzinger, Joseph Cardinal. Creación y Pecado (Creation and Sin). Pamplona: Eunsa, 1992.

Rorty, Richard. Achieving Our Country. Cambridge Mass.: Harvard University Press, 2001.

---. “Comments on Pippin on James.” Inquiry 45.3 (2002): 351-8.

---. Contingency, Irony, and Solidarity. New York: Cambridge University Press, 1989.

---. Hoffnung Statt Erkentniss: Eine Einfuhrung in die Pragmatische Philosophie (Hope instead of Knowledge: An Introduction to Pragmatist Philosophy). Vienna: Passagen Verlag, 1994.

---. Objectivity, Relativism, and Truth. Philosophical Papers, Volume I. Cambridge: Cambridge University Press, 1991.

---. Philosophy as Cultural Politics. Philosophical Papers, Volume IV. Cambridge: Cambridge University Press, 2007.

---. "Pragmatism as Romantic Polytheism.” <http://www.nytimes.com/books/first/d/dickstein-pragmatism.html>.

---. "Religion in the Public Square. A Reconsideration.” Journal of Religious Ethics 3.1 (2003): 141-9.

---. Truth and Progress. Philosophical Papers, Volume III. Cambridge: Cambridge University Press, 1998.

Rorty, Richard and Vattimo Gianni. Il Futuro Della Religione (The Future of Religion). Milan: Garzanti Libri, 2005.

Trigg, Roger. Religion in Public Life. Oxford: Oxford University Press, 2008.

Wolterstorff, Nicholas. “An Engagement with Rorty.” Journal of Religious Ethics 31.1 (2003): 129-39. 